\title{
GENOTYPIC SELECTION ON RED CHILI PLANTS RESISTANT TO ANTHRACNOSE DISEASE AT $M_{2}$ GENERATION
}

\author{
Nyimas Sa'diyah ${ }^{1}$, Adawiah$^{2}$, Ibnu Prasojo ${ }^{3}$, Rugayah$^{1}$, \& Suskandini Ratih Dirmawati ${ }^{4}$ \\ ${ }^{1}$ Department of Agronomy and Horticulture, Faculty of Agriculture, University of Lampung, Indonesia \\ ${ }^{2}$ Magister of Agronomy, ${ }^{3}$ Department of Agrotechnology, Faculty of Agriculture, University of Lampung, Indonesia \\ ${ }^{4}$ Department of Plant Protection, Faculty of Agriculture, University of Lampung, Indonesia \\ Jl. Prof. Dr. Sumantri Brodjonegoro No.1 Bandar Lampung 35145 \\ E-mail: nyimas_diyah@yahoo.com
}

\begin{abstract}
Genotypic selection on red chili plants resistant to anthracnose disease at $M_{2}$ generation. A superior anthracnose resistant cultivar was studied to overcome the low production due to anthracnose in red chili. For the development of superior cultivars, it was necessary to select genotypes that were resistant to anthracnose. Selection effectiveness was determined by wide diversity and high reliability. The purpose of this study was to investigate the diversity and heritability of agronomic characters and resistance to anthracnose on chili plants, and to select genotypes that were resistant to anthracnose. This research was conducted with a design without repetition. The plant material used was the seed of the results of gamma ray mutations in generation $\mathrm{M}_{2}$. The results of this study were: the broad diversity of phenotypes found in all characters observed, while all characters of the genotype observed had broad criteria except plant height at flowering and harvest, and at seedling period. The genotype that should be planted in the next generation was genotype number 136. Genotype number 136 was very resistant to anthracnose infection.
\end{abstract}

Key words: anthrax, diversity, disease resistance, heritability, selection

\begin{abstract}
ABSTRAK
Seleksi genotipe tanaman cabai merah tahan penyakit antraknosa pada generasi $M_{2}$. Kultivar tahan antraknosa unggul dicari untuk mengatasi produksi rendah karena antrasnosa dalam cabai merah. Untuk pengembangan kultivar unggul, perlu untuk memilih genotipe yang resisten terhadap antraknosa. Keefektifan pemilihan ditentukan oleh keanekaragaman yang luas dan keandalan yang tinggi. Tujuan dari penelitian ini adalah untuk melihat keragaman dan heritabilitas karakter agronomi dan ketahanan terhadap antraknosa pada tanaman cabai, dan untuk memilih genotipe yang resisten terhadap antraknosa. Penelitian ini dilakukan dengan desain tanpa pengulangan. Bahan tanaman yang digunakan adalah benih hasil mutasi sinar gamma pada generasi M2. Hasil penelitian ini adalah: keragaman luas fenotip yang ditemukan pada semua karakter yang diamati, sedangkan semua karakter genotipe yang diamati memiliki kriteria luas kecuali tinggi tanaman saat berbunga dan panen, dan pada periode pembibitan. Genotipe yang harus ditanam pada generasi berikutnya adalah nomor genotipe 136. Nomor genotipe 136 sangat tahan terhadap infeksi antraknosa.
\end{abstract}

Kata kunci: antraks, heritabilitas, keanekaragaman, resistensi penyakit, seleksi

\section{INTRODUCTION}

Chili productivity in 2016 was 8.47 tons/ha. Production of 8.47 tons/ha was still relatively low (Badan Pusat Statistik, 2017). One of the causes of low chili production was lack high-quality seeds and high pest and disease infections. Pest and disease infections were the most dominant factors in reducing chili productivity in Indonesia (Hakim et al., 2014).

One of the important diseases in chili production in the tropics and humid regions is anthracnose. Anthracnose is a disease caused by fungus
Colletotrichum spp. This pathogen can infect before and after plant harvest and reduce production up to $50 \%$ or more (Nurhayati, 2007; Syukur et al., 2009). The use of superior varieties resistant to anthracnose is an effort to overcome the problem of anthrax infection. Therefore, it is necessary to develop superior cultivars resistant to anthracnose.

The development of superior cultivars is began with the selection from the diverse existing sources. Selection of effectiveness is determined by the diversity width. One source of diversity could be obtained by mutation. Mutations are change in genetic material. 
Mutation was one method that had been shown to increase genetic diversity which could be applied to support plant breeding programs (Yunita et al., 2014).

Mutation induction mostly used gamma irradiation because gamma rays irradiation had a higher frequency of mutation results and was easier to apply (Gaswanto et al., 2016), gamma rays had high energy, on crossing plant material could cause changes in the tissue itself, cells, structure or composition of genetic material (genomes, chromosomes, genes, DNA). Changes in the genetic traits of these plants went to the direction of better or worse (Soeranto, 2003). In addition to the wide diversity, the effectiveness of selection was determined by the estimated high heritability. The estimated value of high heritability meant that genetic factors had more role than environmental factors.

Gaswanto et al. (2015) conducted a mutation study using gamma rays to obtain chili which was categorized as resistant and rather resistant to Begomovirus infection. Manzila et al. (2015) reported that chili mutations using ethyl methanesulfonate (EMS) to produce mutant chili lines that were resistant to tolerance to chili venal mottle virus (ChiVMV).

This study was initiated by mutating chili seeds in August 2016. The doses used were 0 Gy (without irradiation), $100 \mathrm{~Gy}, 200 \mathrm{~Gy}, 300 \mathrm{~Gy}$, and $400 \mathrm{~Gy}$. Mutation results were planted in October 2016 until March 2017. The results obtained, there were differences in the appearance of each dose. The higher dose of gamma rays, the shorter the seeds that grew. This showed that the influence of mutations on the growth of chili seedlings (Sa'diyah, 2016). At the dose of 300 Gy the seed weight was the highest (Sa'diyah et al., 2017). Therefore, what continued on the next planting was the seed of generation $\mathrm{M}_{2}$ from the dose of $300 \mathrm{~Gy}$.

In this study, it was expected that chili plants that were irradiated with gamma rays experienced genetic changes in a better, lowered direction and could lead to a wide diversity. Therefore, the purpose of this study was to understand whether the changes in nature occurred or not, judging with the estimated value of heritability. In addition, it was also seen whether diversity occurred in generation $\mathrm{M}_{2}$. The best genotype selection was based on diversity, the estimated value of high heritability, resistance to anthracnose disease and the large number of fruits.

\section{MATERIALS AND METHODS}

Research Site. This study was conducted in the integrated field laboratory of the Faculty of Agriculture,
University of Lampung from June to December 2017. Gamma radiation had been carried out at the Research and Development Center for Isotopes and Radiation Technology, Pasar Jumat, Jakarta in August 2016.

Planting material used in this study were 84 generation $\mathrm{M}_{2}$ chili seeds (second generation mutations) from the Ferosa variety given a dose of $300 \mathrm{~Gy}$. Plants produced from the seeds of generation $\mathrm{M}_{2}$ each had differences due to gamma ray mutations. Therefore, observation and inoculation was carried out on each plant.

Inoculation was done by spraying a suspension of spores of Colletotrichum spp. at a density of $10^{6}$ spore $/ \mathrm{mL}$ at flowers and early fruiting stages. The suspension of the Colletotrichum spp. spore was made by means of Colletotrichum spp. isolated from anthracnose-like infected chili. The anthracnose-chili peppers were cut in size of $2 \mathrm{~mm}^{2}$ and then incubated on PDA media, then purified by being transferred to the next PDA media until pure spores of Colletotrichum spp were harvested from one week old isolates. The spores then were suspended in $30 \mathrm{~mL}$ of distilled water.

Variables observed were: anthracnose disease resistance, seed height, number of primary branches, plant height at flowering, plant height at harvest, flowering age, number of flowers, harvest age, incubation period, and number of fruits. Resistance to anthracnose was measured based on the incidence of disease. Scores and criteria for resistance to anthrax were measured using Yoon's modified method of Syukur et al. (2007) (Table 1). The occurrence of disease or disease incidence (DI) was calculated using the formula:

$$
\mathrm{DI}=\left(\frac{\mathrm{n}}{\mathrm{N}}\right) \times 100 \%
$$

$\mathrm{DI}=$ disease incidence

$\mathrm{n}=$ number of infected fruits

$\mathrm{N}=$ total fruit number

Analyses of the range of phenotypes $\left(\sigma_{f}^{2}\right)$, environmental variance $\left(\sigma_{e}^{2}\right)$, and genetic variance $\left(\sigma_{g}^{2}\right)$ were calculated as:

$$
\sigma_{p}^{2}=\frac{\sum_{i=I}^{n}(X i-\mu)^{2}}{N} \quad \begin{gathered}
\sigma \frac{2}{e}=\sigma_{P}^{2} \mathrm{M}_{0} \\
\sigma_{g}^{2}=\sigma_{p}^{2}-\sigma_{e}^{2}
\end{gathered}
$$

$\sigma_{g}^{2}=$ variability of genotypes

$\mathrm{Xi}=$ value of plant observations to $-\mathrm{i}$

$\mu \quad=$ mean population value

$\mathrm{N}$ = number of plants observed

$\sigma_{p}^{2}=$ variability of phenotypes

$\sigma_{e}^{2}=$ variability of environments 
The variability of phenotypes observed in the parent population was the same as the environment because the population of parents was genetically uniform and the variability of genotypes was zero. The variability of environmental of the parental population was as the same as that of the offspring since the parental and their offspring populations were planted in the same environment. The standard deviation calculation formula $\left(\sqrt{\sigma^{2}}\right)$ is:

$$
\sqrt{\sigma^{2}}=\sqrt{\frac{\sum_{i=I}^{n}(X i-\mu)^{2}}{N}}
$$

$\sqrt{\sigma^{2}}=$ standard deviation

$\mathrm{Xi} \quad=$ observation value to $-\mathrm{i}$

$\mu \quad=$ mean population value

$\mathrm{N} \quad=$ number of plants observed.

Estimating heritability in the broadest sense $(\mathrm{H})$ used the formula:

$$
\mathrm{H}=\frac{\sigma_{\mathrm{g}}^{2}}{\sigma_{\mathrm{f}}^{2}}
$$

$\mathrm{H}_{2} \quad=$ broad sense heritability

$\sigma_{g}^{2} \quad=$ variability of genotypes

$\sigma_{f}^{2} \quad=$ variability of phenotypes.

Remark: High heritability $(\mathrm{H}>0.5)$; Moderate heritability $(0.2<\mathrm{H}<0.5)$; Low heritability $(\mathrm{H}<0.2)$ (MendezNatera et al., 2012).

The best genotype criteria were based on wide diversity, high predictability of heritability and great resistance to anthracnose.

\section{RESULTS AND DISCUSSION}

The Diversity of Phenotypes and Genotypes. The diversity of phenotypes for the characteristics of seedling height, number of primary branches, flowering age, number of flowers, plant height at flowering, age of harvest, plant height, incubation period, and number of $\mathrm{M}_{2}$ generation chili characterized as broad criteria
(Table 2). The same results were obtained by Syukur $e t$ al. (2010) where the characters of plant height, flowering age, harvest age, and the number of chili plants had a wide diversity of phenotypic values.

Almost all variables had wide genotype diversity except the characters of plant height at flowering, plant height at harvest, and the incubation period (Table 2). Narrow genotype diversity on the characters of plant height at flowering and plant height at harvest was similar with the research conducted by Nura (2015). In the Nura's study (2015) it was shown that plant height character had a narrow diversity of genotypes. The narrow range of genotypes explained that plants were genetically uniform. Plants that were genetically uniform could cause the selection process to the next generation to be less effective (Aryana, 2012). This meant that there was no need to do a selection based on characters that had a narrow diversity of genotypes.

In general, a character that had a wide variability of genotypes would have a wide variability of phenotypes as well. However, in this study there were characters who had narrow genetic diversity but had a wide variability of phenotypes. The wide variability of phenotypes showed that there were differences in appearance on these characters, because the expressions varied in the same genotype.

Values of Estimated Heritability. Value of heritability for resistance character, seed height and number of primary branches classed in the high criteria. The character of the number of fruits was classed in the criteria of moderate. The estimated heritabilities classed in the low criteria were the character of flowering age, number of flowers, plant height at flowering, harvest age, crop height at harvest, and incubation period (Table 3 ). There were differences in criteria between this study and the research conducted by Satriawan et al. (2017). Satriawan et al. (2017) conducted a study on $\mathrm{F}_{2}$ generation chili plants found that the estimated value of heritability was influenced by the character of the population, the evaluated genotype sample, calculation method, flexibility of genotype evaluation, linkage imbalance, and experimentation.

Table 1. Chili resistance scores and criteria for anthracnose based on disease incidence

\begin{tabular}{ccc}
\hline Score & Incidence $(\%)$ & Criteria \\
\hline 1 & $0-10$ & Highly Resistant \\
2 & $11-20$ & Resistant \\
3 & $21-40$ & Moderate Resistant \\
4 & $41-70$ & Susceptible \\
5 & $>70$ & Highly Susceptible \\
\hline
\end{tabular}


The high predictive value of heritability in a character indicated that the phenotype produced by the character was determined by genetic factors rather than environmental factors. In contrast, low heritability showed that the appearance produced was determined by environmental factors rather than genetic factors. Moderate heritability showed that the character phenotype was influenced by genetic factors and environmental factors of equal size (Satriawan et al., 2017; Syukur et al. (2011). Some characters had a heritability value of 0.00 , which was the characters of flowering plants, crop height and the incubation period, similar to that reported by Maryenti et al. (2015) who obtained a heritability value of 0.00 . This occurred because the genotype diversity of the character was negative. The diversity that had a genotype value that was negative was considered zero (Hallauer \& Miranda,
1988), so the value of the heritability would also be equal to zero.

Resistance to Anthrax Disease. Resilience to anthracnose in chili was predicted based on the incidence of the disease. Disease events were used to determine the score and criteria for resistance to anthracnose in chili (Syukur et al., 2007). Disease was observed from the fruit with symptoms on green fruit and red fruit after inoculation during the flowering phase and fruiting phase.

The lowest disease resistance score for anthracnose in generation $\mathrm{M}_{2}$ was found in genotypes number 136 and 93 (Table 4), indicating that genotypes number 136 and 93 had resistance to anthracnose disease. Genotype number 136 was infected by anthrax at the time of the red fruit harvest with a percentage of

Table 2. Variability criteria for phenotype and genotype of $\mathrm{M}_{2}$ generation mutant chili

\begin{tabular}{lcccc}
\hline Character & $\sigma_{f}^{2}$ & Criteria & $\sigma_{g}^{2}$ & Criteria for \\
\hline Seedling height & 46.22 & Wide & 43.99 & Wide \\
Number of prima branches & 52.37 & Wide & 35.62 & Wide \\
Age of flowering & 1609.95 & Wide & 214.16 & Wide \\
Number of flower & $192,642.06$ & Wide & 9625.58 & Wide \\
Plant height at flowering & 516,34 & Wide & 0 & Narrow \\
Age of harvest & 10911,18 & Wide & 2013.16 & Wide \\
Plant height at harvest & 2502.44 & Wide & -1100.43 & Narrow \\
Incubation Period & 135.40 & Wide & 0 & Narrow \\
Severity of disease & 207.50 & Wide & 149.09 & Wide \\
Number of fruits & 6215.91 & Wide & 1502.61 & Wide \\
\hline
\end{tabular}

Diversity criteria based on Anderson and Banchrof in Wahdah (1996) were $\sigma_{f}^{2}>2 \sigma_{f}^{2}$ : wide diversity and $\sigma_{f}^{2}<2 \sigma_{f}^{2}$ : narrow diversity. $\sigma_{g}^{2}>2 \sigma_{g}^{2}$ : wide diversity and $\sigma_{g}^{2}<2 \sigma_{g}^{2}$ : narrow diversity.

Table 3. Heritability in the broad sense of generation $\mathrm{M}_{2}$ mutant chili

\begin{tabular}{lcc}
\hline \multicolumn{1}{c}{ Character } & $\mathrm{H}$ & Criteria \\
\hline Seed & 0.95 & High \\
Number of primary branching & 0.68 & High \\
Age of flowering & 0.13 & Low \\
Number of flower & 0.05 & Low \\
Plant height at flowering & 0,00 & Low \\
Age of harvest & 0,18 & Low \\
Plant height at harvest & 0,00 & Low \\
Incubation period & 0,00 & Low \\
Severity of disease & 0,75 & High \\
Number of fruit & 0,24 & Moderate \\
\hline
\end{tabular}

High heritability $(\mathrm{H}>0,5)$; Moderate heritability $(0.2<\mathrm{H}<0.5)$; Low heritability $(\mathrm{H}<0.2)($ Mendez-Natera, 2012). 
Table 4. Criteria for resistance to anthracnose in chili varieties Ferosa generation $M_{2}$

\begin{tabular}{|c|c|c|c|c|c|c|c|}
\hline $\begin{array}{c}\text { No Gen. } \\
\text { M2 }\end{array}$ & $\begin{array}{l}\text { Healthy } \\
\text { red fruit }\end{array}$ & $\begin{array}{l}\text { Infected } \\
\text { red fruit }\end{array}$ & $\begin{array}{c}\text { Green } \\
\text { fruit } \\
\text { infected }\end{array}$ & $\begin{array}{c}\text { Total } \\
\text { infected } \\
\text { fruit }\end{array}$ & $\begin{array}{c}\text { Fruit } \\
\text { numbers }\end{array}$ & DI & Criteria \\
\hline 136 & 41 & 1 & 0 & 1 & 42 & 2.38 & Highly Resistant \\
\hline 93 & 21 & & 0 & 2 & 23 & 8.70 & Highly Resistant \\
\hline 94 & 13 & 4 & 8 & 12 & 25 & 48 & Susceptible \\
\hline 127 & 12 & 5 & 8 & 13 & 25 & 52 & Susceptible \\
\hline 132 & 11 & 0 & 13 & 13 & 24 & 54,17 & Susceptible \\
\hline 63 & 16 & 8 & 13 & 21 & 37 & 56,76 & Susceptible \\
\hline 144 & 12 & 4 & 31 & 35 & 47 & 74,47 & Highly Suscept \\
\hline 79 & 12 & 1 & 36 & 37 & 49 & 75,51 & Highly suscept \\
\hline 76 & 7 & 12 & 12 & 24 & 31 & 77.42 & Highly suscept \\
\hline 22 & 10 & 8 & 28 & 36 & 46 & 78.26 & Highly suscept \\
\hline 142 & 11 & 7 & 34 & 41 & 52 & 78.85 & Highly suscept \\
\hline 115 & 10 & 10 & 28 & 38 & 48 & 79.17 & Highly suscept \\
\hline 121 & 14 & 1 & 53 & 54 & 68 & 79,41 & Highly suscept \\
\hline 147 & 9 & 0 & 37 & 37 & 46 & 80.43 & Highly suscept \\
\hline 105 & 3 & 5 & 8 & 13 & 16 & 81.25 & Highly suscept \\
\hline 35 & 5 & 5 & 18 & 23 & 28 & 82.14 & Highly suscept \\
\hline 58 & 22 & 5 & 99 & 104 & 126 & 82.54 & Highly suscept \\
\hline 125 & 5 & 5 & 20 & 25 & 30 & 83,33 & Highly suscept \\
\hline 131 & 9 & 3 & 43 & 46 & 55 & 83,64 & Highly suscept \\
\hline 84 & 14 & 9 & 70 & 79 & 93 & 84,95 & Highly suscept \\
\hline 65 & 5 & 10 & 19 & 29 & 34 & 85,29 & Highly suscept \\
\hline 61 & 3 & 0 & 19 & 19 & 22 & 86,36 & Highly suscept \\
\hline 114 & 5 & 1 & 34 & 35 & 40 & 87.5 & Highly suscept \\
\hline 145 & 6 & 3 & 42 & 45 & 51 & 88.24 & Highly suscept \\
\hline 82 & 3 & 3 & 20 & 23 & 26 & 88.46 & Very susceptible \\
\hline 91 & 5 & 0 & 39 & 39 & 44 & 88,64 & Highly suscept \\
\hline 78 & 4 & 2 & 32 & 34 & 38 & 89,47 & Highly suscept \\
\hline 28 & 8 & 1 & 75 & 76 & 84 & 90,48 & Highly suscept \\
\hline 150 & 4 & 1 & 38 & 39 & 43 & 90,70 & Highly suscept \\
\hline 32 & 10 & 16 & 82 & 98 & 108 & 90.74 & Highly suscept \\
\hline 68 & 6 & 7 & 53 & 60 & 66 & 90.91 & Highly suscept \\
\hline 70 & 9 & 11 & 96 & 107 & 116 & 92.24 & Highly suscept \\
\hline 122 & 2 & 0 & 24 & 24 & 26 & 92.31 & Highly suscept \\
\hline 108 & 8 & 6 & 92 & 98 & 106 & 92.45 & Highly suscept \\
\hline 73 & 20 & 50 & 196 & 246 & 266 & 92.48 & Highly suscept \\
\hline 90 & 29 & 37 & 326 & 363 & 392 & 92.60 & Highly suscept \\
\hline 37 & 7 & 20 & 69 & 89 & 96 & 92.71 & Highly suscept \\
\hline 2 & 1 & 0 & 13 & 13 & 14 & 92.86 & Highly suscept \\
\hline 46 & 4 & 7 & 47 & 54 & 58 & 93.10 & Highly suscept \\
\hline 43 & 6 & 7 & 77 & 84 & 90 & 93.33 & Highly suscept \\
\hline 137 & 3 & 0 & 48 & 48 & 51 & 94.12 & Highly suscept \\
\hline 57 & 11 & 11 & 182 & 193 & 204 & 94.61 & Highly suscept \\
\hline 51 & 2 & 4 & 32 & 36 & 38 & 94.74 & Highly suscept \\
\hline 111 & 4 & 1 & 77 & 78 & 82 & 95.12 & Highly suscept \\
\hline
\end{tabular}


Table 4. Continued

\begin{tabular}{|c|c|c|c|c|c|c|c|}
\hline $\begin{array}{c}\text { No Gen. } \\
\text { M2 }\end{array}$ & $\begin{array}{l}\text { Healthy } \\
\text { red fruit }\end{array}$ & $\begin{array}{l}\text { Infected } \\
\text { red fruit }\end{array}$ & $\begin{array}{c}\text { Green } \\
\text { fruit } \\
\text { infected }\end{array}$ & $\begin{array}{c}\text { Total } \\
\text { infected } \\
\text { fruit }\end{array}$ & $\begin{array}{c}\text { Fruit } \\
\text { numbers }\end{array}$ & DI & Criteria \\
\hline 141 & 4 & 0 & 79 & 79 & 83 & 95.18 & Highly suscept \\
\hline 34 & 1 & 6 & 14 & 20 & 21 & 95.24 & Highly suscept \\
\hline 47 & 1 & 2 & 19 & 21 & 22 & 95.45 & Highly suscept \\
\hline 55 & 2 & 0 & 46 & 46 & 48 & 95,83 & Highly suscept \\
\hline 7 & 1 & 2 & 27 & 29 & 30 & 96.67 & Highly suscept \\
\hline 33 & 2 & 0 & 58 & 58 & 60 & 96.67 & Highly suscept \\
\hline 15 & 1 & 0 & 30 & 30 & 31 & 96.77 & Highly suscept \\
\hline 80 & 5 & 1 & 150 & 151 & 156 & 96.79 & Highly suscept \\
\hline 29 & 4 & 15 & 112 & 127 & 131 & 96.95 & Highly suscept \\
\hline 81 & 2 & 0 & 66 & 66 & 68 & 97.06 & Highly suscept \\
\hline 49 & 1 & 3 & 32 & 35 & 36 & 97.22 & Highly suscept \\
\hline 21 & 5 & 19 & 157 & 176 & 181 & 97.24 & Highly suscept \\
\hline 48 & 7 & 6 & 243 & 249 & 256 & 97.27 & Highly suscept \\
\hline 64 & 2 & 2 & 70 & 72 & 74 & 97.30 & Highly suscept \\
\hline 13 & 3 & 9 & 108 & 117 & 120 & 97.5 & Highly suscept \\
\hline 92 & 1 & 9 & 35 & 44 & 45 & 97.78 & Highly suscept \\
\hline 106 & 2 & 0 & 94 & 94 & 96 & 97.92 & Highly suscept \\
\hline 31 & 1 & 26 & 23 & 49 & 50 & 98 & Highly suscept \\
\hline 53 & 1 & 0 & 49 & 49 & 50 & 98 & Highly suscept \\
\hline 130 & 1 & 0 & 49 & 49 & 50 & 98 & Highly suscept \\
\hline 107 & 1 & 12 & 48 & 60 & 61 & 98.36 & Highly suscept \\
\hline 71 & 1 & 2 & 60 & 62 & 63 & 98.41 & Highly suscept \\
\hline 72 & 1 & 0 & 65 & 65 & 66 & 98.48 & Highly suscept \\
\hline 24 & 2 & 2 & 132 & 134 & 136 & 98.53 & Highly suscept \\
\hline 39 & 1 & 18 & 58 & 76 & 77 & 98.70 & Highly suscept \\
\hline 62 & 1 & 0 & 77 & 77 & 78 & 98.72 & Highly suscept \\
\hline 8 & 1 & 0 & 90 & 90 & 91 & 98.90 & Highly suscept \\
\hline 26 & 1 & 4 & 87 & 91 & 92 & 98.91 & Highly suscept \\
\hline 128 & 1 & 3 & 90 & 93 & 94 & 98.94 & Highly suscept \\
\hline 20 & 1 & 3 & 162 & 165 & 166 & 99.40 & Highly suscept \\
\hline 3 & 0 & 9 & 39 & 48 & 48 & 100 & Highly suscept \\
\hline 6 & 0 & 8 & 150 & 158 & 158 & 100 & Highly suscept \\
\hline 11 & 0 & 1 & 103 & 104 & 104 & 100 & Highly suscept \\
\hline 12 & 0 & 5 & 252 & 257 & 257 & 100 & Highly suscept \\
\hline 16 & 0 & 4 & 46 & 50 & 50 & 100 & Highly suscept \\
\hline 45 & 0 & 2 & 89 & 91 & 91 & 100 & Highly suscept \\
\hline 66 & 0 & 7 & 54 & 61 & 61 & 100 & Highly suscept \\
\hline 74 & 0 & 2 & 40 & 42 & 42 & 100 & Highly suscept \\
\hline 75 & 0 & 2 & 88 & 90 & 90 & 100 & Highly suscept \\
\hline 118 & 0 & 12 & 12 & 24 & 24 & 100 & Highly suscept \\
\hline
\end{tabular}

$\mathrm{DI}=$ Disease Incidence. Resilience Criteria $=$ Very Resistant, DI: 0-10 \%; Resistant, DI: 11-20 \%; Moderate Resistant, DI: 21-40 \%; Susceptible, DI: 41-70\%; Highly Susceptible, DI:> 70\%. 
$2.38 \%$ disease incidence, and on genotype 93 the percentage of disease incidence was $8.70 \%$. There were several genotypes where $0 \%$ infection on red fruit could not be classed in low category because several genotypes with a percentage of $0 \%$ in the red fruit harvest produced a high percentage of infection when the fruits were green. This was because the incubation period of the disease on each genotype was different. In addition, many of the $0 \%$ infection percentage in red fruit did not have red fruit because fruit had symptoms of the disease when green. The lowest infection during the green harvest was found in genotypes number 94 and 136 with $0 \%$ infection percentage, this indicated that the infection did not occur when the fruit was green.
In generation $\mathrm{M}_{2}$, there were genotypes that had resistance to anthracnose, namely genotypes 136 and 93 (Table 4), while generation $\mathrm{M}_{0}$ or without mutation (Table 5) all tested plants were very susceptible to anthracnose disease. This showed an increase in resistance to chili anthracnose disease due to $300 \mathrm{~Gy}$ gamma ray mutations. This increased resistance to anthrax was a positive expression of mutating genes.

Selection of the Best Genotypes. Phenotype was an observable characteristic of an organism that was regulated by genotype and environment and the interaction between genotypes and the environment. Genotype was an individual's genetic state. Selection

Table 5. Criteria for resistance to anthracnose in the varieties of Ferosa generation $M_{0}$

\begin{tabular}{|c|c|c|c|c|c|c|c|c|}
\hline No.plants & $\begin{array}{l}\text { Healthy } \\
\text { red fruit }\end{array}$ & $\begin{array}{l}\text { Infected } \\
\text { red fruit }\end{array}$ & $\begin{array}{l}\text { Infected } \\
\text { green } \\
\text { fruit }\end{array}$ & $\begin{array}{c}\text { Total } \\
\text { infected } \\
\text { fruit }\end{array}$ & $\begin{array}{c}\text { Fruit } \\
\text { number }\end{array}$ & DI & Score & $\begin{array}{c}\text { Resilience } \\
\text { Criteria }\end{array}$ \\
\hline 9 & 1 & 0 & 24 & 38 & 47 & 80.85 & 5 & Highly suscept \\
\hline 21 & 8 & 5 & 77 & 22 & 26 & 84.62 & 5 & Highly suscept \\
\hline 24 & 0 & 4 & 78 & 38 & 44 & 86.36 & 5 & Highly suscept \\
\hline 18 & 1 & 0 & 31 & 54 & 61 & 88.52 & 5 & Highly suscept \\
\hline 2 & 0 & 3 & 257 & 82 & 90 & 91.11 & 5 & Highly suscept \\
\hline 17 & 0 & 1 & 45 & 25 & 27 & 92.59 & 5 & Highly suscept \\
\hline 16 & 3 & 3 & 69 & 41 & 43 & 95.35 & 5 & Highly suscept \\
\hline 8 & 4 & 6 & 88 & 94 & 98 & 95.92 & 5 & Highly suscept \\
\hline 1 & 9 & 7 & 31 & 24 & 25 & 96 & 5 & Highly suscept \\
\hline 7 & 0 & 4 & 64 & 72 & 75 & 96 & 5 & Highly suscept \\
\hline 4 & 0 & 14 & 32 & 31 & 32 & 96,88 & 5 & Highly suscept \\
\hline 20 & 0 & 0 & 79 & 34 & 35 & 97.14 & 5 & Highly suscept \\
\hline 26 & 0 & 0 & 77 & 40 & 41 & 97.56 & 5 & Highly suscept \\
\hline 22 & 0 & 0 & 42 & 48 & 49 & 97.96 & 5 & Highly suscept \\
\hline 3 & 2 & 0 & 41 & 82 & 82 & 100 & 5 & Highly suscept \\
\hline 5 & 2 & 0 & 25 & 260 & 260 & 100 & 5 & Highly suscept \\
\hline 6 & 7 & 2 & 52 & 46 & 46 & 100 & 5 & Highly suscept \\
\hline 10 & 0 & 0 & 48 & 68 & 68 & 100 & 5 & Highly suscept \\
\hline 11 & 1 & 0 & 34 & 46 & 46 & 100 & 5 & Highly suscept \\
\hline 12 & 4 & 0 & 22 & 79 & 79 & 100 & 5 & Highly suscept \\
\hline 13 & 1 & 2 & 46 & 77 & 77 & 100 & 5 & Highly suscept \\
\hline 14 & 0 & 0 & 22 & 42 & 42 & 100 & 5 & Highly suscept \\
\hline 19 & 6 & 0 & 38 & 48 & 48 & 100 & 5 & Highly suscept \\
\hline 23 & 0 & 0 & 32 & 22 & 22 & 100 & 5 & Highly suscept \\
\hline 25 & 1 & 1 & 39 & 32 & 32 & 100 & 5 & Highly suscept \\
\hline Average & 2 & 2 & 56 & 57.8 & 60 & 95.87 & 5 & Highly suscept \\
\hline
\end{tabular}

$\mathrm{DI}=$ Disease Incidence. Resilience Criteria= Very Resistant, DI: 0-10\%; Resistant, DI: 11-20\%; Moderate Resistant, DI: 21-40\%; Susceptible, DI: 41-70\%; Highly Susceptible, DI: > 70\%. 
would be effective if a character had a broad genotype diversity criterion and a high predictive value for heritability. In character studies which had a wide variety of genotypes there were characteristics of disease resistance, seedling height, number of primary branches, flowering age, harvest age, number of flowers, and number of fruits. However, the estimated value of heritability with high criteria was only on the character of disease resistance, seedling height and number of primary branches. This meant that the selection would be effective on the character of the resistance to disease of the seedlings and the number of primary branches. The character of the number of fruits had a wide variability of genotypes and the estimated value of heritability was moderate, so the character of the number of fruits could also be considered as a selection criterion.

Based on the resistance to anthracnose, the plants which would be continued in the next generation were plants of genotype 136 and 93. In genotype 136, the number of healthy red chili fruits was 41 , infected on one red fruit and without infection on green fruits. In genotype 93, there were 21 healthy red chili fruits, 2 red fruits were infected and no infection on green fruits. However, the number of fruits in genotype 136 was only 42 and genotype 93 only 23 which were very low when compared to genotype 90 with 29 healthy red fruits, 37 infected red fruit, 326 infected green fruits. Genotype 136 had $10 \mathrm{~cm}$ seedling height and 4 primary branches, plant number 93 had $10.5 \mathrm{~cm}$ seedling height and 4 primary branches, while genotype 90 had $10.5 \mathrm{~cm}$ seedling height and 7 primary branches.

\section{CONCLUSION}

All observation characters had a wide diversity of phenotypes. Almost all of the characters observed had a wide diversity of genotypes, except for plant height at the beginning of flowering, plant height at harvest, and incubation period which had a narrow diversity of genotypes. High heritability was found in seed height, number of primary branches and severity of disease, while moderate heritability in fruit counts per plant. The selected genotypes based on anthracnose disease resistance were genotypes number 136 and 93.

\section{ACKNOWLEDGMENTS}

This study wa a prioritized study with the University of Lampung PNBP funds in 2017. The authors would like to thank the University of Lampung for funding this research.

\section{REFERENCES}

Aryana IGPM. 2012. Uji keseragaman, heritabilitas dan kemajuan genetik galur padi beras merah hasil seleksi silang balik di lingkungan gogo. Crop Agro. 3(1): 12-20.

Badan Pusat Statistik. 2017. Produksi Cabai Besar Menurut Provinsi 2011-2015. Badan Pusat Statistik Indonesia. Jakarta.

Gaswanto R, Syukur M, Purwoko BS, \& Hidayat SH. 2015. Metode penularan massal untuk uji penapisan ketahanan cabai mutan terhadap Begomovirus. J. Hort. 25(3): 246-256.

Gaswanto R, Syukur M, Purwoko BS, \& Hidayat SH. 2016. Induced mutation by gamma rays irradiation to increase chilli resistance to Begomovirus. AGRIVITA. 38 (1): 24-32.

Hallauer AR \& Miranda JB. 1988. Quantitative Genetics in Maize Breeding. Second Edition. Iowa State University Press/Ames. Iowa.

Hakim A, Syukur M, \& Widodo. 2014. Ketahanan penyakit antraknosa terhadap cabai lokal dan cabai introduksi. Bul. Agrohorti. 2(1): 31-36.

Mendez-Natera JR, Rondon A, Hernandes J, \& Merazo-Pinto JF. 2012. Genetic studies in upland cotton. III. Genetic parameters, correlation and path analysis. SABRAO J. Breed. Genet. 44(1): 112-128.

Manzila I, Gunaeni N, Kusandriani Y, \& Priyatno TP. 2015. Ketahanan dan karakter fenotipe galur mutan $\left(\mathrm{M}_{2}\right)$ cabai terhadap Chilli Veinal Mottle Virus. J. AgroBiogen. 11(2): 73-80.

Maryenti T, Barmawi M, \& Prasetyo J. 2015. Heritabilitas dan kemajuan genetik karakter ketahanan kedelai generasi $\mathrm{F}_{2}$ persilangan Tanggamus x $\mathrm{B}_{3570}$ terhadap Soybean mosaic virus. J. KELITBANGAN. 2(2): 137-153.

Nurhayati, 2007. Pertumbuhan Colletotrichum capsici penyebab antraknosa buah cabai pada berbagai media yang mengandung ekstrak tanaman. $J$. Rafflesia. 9(1): 32-35.

Nura. 2015. Peningkatan Keragaman Genetik Cabai Tahan terhadap Penyakit Antraknosa Melalui Hibridisasi dan Iradiasi Sinar Gamma. Tesis. Institut Pertanian Bogor. Bogor. 
Sa'diyah N. 2016. Pengaruh iradiasi sinar gamma pada benih terhadap pembibitan cabai (Capsicum annuиm L.). Laporan Penelitian.

Sa'diyah N, Aksuri F, Azhari MF, \& Rugayah. 2017. Pengaruh iradiasi sinar gamma pada benih terhadap keragaman genotipe dan fenotipe cabai merah. Dalam: Soleh MA, Kadapi M, Mubarok S, Wicaksono FY, \& Sari S (Eds.). Prosiding Seminar Nasional Pemanfaatan Tanaman Lokal untuk Pangan dan Industri. pp.138-144. Universitas Padjajaran, Jatinangor Sumedang. 3 Agustus 2017.

Satriawan IB, Sugiharto AN, \& Ashari S. 2017. Heritabilitas dan kemajuan genetik tanaman cabai merah (Capsicum annuum L.) generasi $\mathrm{F}_{2} . J$. Produksi Tanaman. 5(2): 343-348.

Soeranto H. 2003. Peran Iptek nuklir dalam pemuliaan untuk mendukung industri pertanian. Dalam: Sukarsono R, Abraha K \& Arryanto Y (Eds.). Prosiding Pertemuan dan Presentasi Ilmiah Penelitian Dasar Ilmu Pengetahuan dan Teknologi Nuklir P3TM Batan. pp. 308-316. Yogyakarta. 27 Juni 2002.

Syukur M, Sujiprihati S, Koswara J, \& Widodo. 2007. Pewarisan ketahanan cabai (Capsicum annuum L.) terhadap Antraknosa yang disebabkan oleh Colletotrichum acutatum. Bul. Agron. 35 (2): 112-117.
Syukur M, Sujiprihati S, Koswara J, \& Widodo. 2009. Ketahanan terhadap antraknosa yang disebabkan oleh Colletotrichum acutatum pada beberapa genotipe cabai (Capsicum annuum L.) dan korelasinya dengan kandungan kapsaicin dan peroksidase. J. Agron. Indonesia. 37(3): 233239.

Syukur M, Sujiprihati S, Yunianti R, \& Nida K. 2010. Pendugaan komponen ragam, heritabilitas dan korelasi untuk menentukan kriteria seleksi cabai (Capsicum annuum L.) Populasi F5. J. Hort. Indonesia. 1(2): 74-80.

Syukur M, Sujiprihati S, Yunianti R, \& Kusumah DA. 2011. Pendugaan ragam genetik dan heritabilitas karakter komponen hasil beberapa genotipe cabai. J. Agrivigor. 10(2): 148-156.

Wahdah R. 1996. Variabilitas dan Pewarisan Laju Akumulasi Bahan Kering pada Biji Kedelai. Disertasi. Universitas Padjadjaran. Bandung.

Yunita R, Khumaida N, Sopandie D, \& Mariska I. 2014. Pengaruh iradiasi sinar gama terhadap pertumbuhan dan regenerasi kalus padi varietas ciherang dan inpari 13. J. AgroBiogen. 10(3): 101-108. 